\title{
The Modern Chemical Theory of Ovarian Cancer Origin
}

\author{
MIHAELA ALINA CALIN ${ }^{1}$, ELENA MIHALCEANU2*, MIHAELA DEBITA ${ }^{1 *}$, GHEORGHE RAFTU³, GABRIEL COSTACHESCU², \\ GETA MITREA ${ }^{1}$ \\ 'Dunarea de J os University of Galati, Medicine and Pharmacy Faculty, 47 Domneasca Str., 800008, Galati, Romania. \\ ${ }^{2}$ Grigore T. Popa University of Medicine and Pharmacy lasi, Faculty of Medicine, Department of Mother and Child, 16 Universitatii \\ Str., 700115, Iasi, Romania \\ ${ }^{3}$ Ovidius University of Constanta, Faculty of Dental Medicine, 124 Mamaia Blvd., 900527, Constanta, Romania
}

\begin{abstract}
Because of its histological and embryological complex development, the ovary can be the source of a large variety of tumors, ovarian cancer being the fifth female neoplasia as a frequency. A major clinical significance is that the ovarian tumor is asymptomatic for a long period of time.Ovarian proliferative pathology raises a number of important issues from both theoretical and practical point of view. The change in the therapeutic attitude, especially in the areas of surgery and chemotherapy, has led in the last decades to an improvement in the survival rate. Our retrospective study included the analysis of 64 patients with ovarian cancer. Ovarian neoplasms should have a multidisciplinary approache with individualized treatment for each patient. The long-term survival remains, however, the detection of the tumor at an early stage, the undetectment in the initial stages leading to a survival rate of 5 years less than $20 \%$.
\end{abstract}

Keywords: ovarian cancer, risk factors, factori de risc, screening.

Because of its histological and embryological complex development, the ovary can be the source of a large variety of tumors, ovarian cancer being the fifth female neoplasia as a frequency. A major clinical significance is that the ovarian tumor is asymptomatic for a long period of time [1-3].

The characteristic of ovarian tumors is underlined by the following findings: it shows a high degree of macroscopic polymorphism, starting from the periphery towards the center of the tumor and microscopically, sometimes in the same section encountering a multitude of aspects [4-6]. The incidence of the disease is increasing, the history and clinical aspects are nonspecific, and the varied nature of the patients, early diagnosis is difficult or even impossible to consider [ 7-9].

The staging is based on clinical, anatomopathological and surgical criteria. Surgery is followed by numerous relapses if it is not combined with the specific oncology [10-12].

Ovarian cancer should be resolved, if the situation so permits, by surgery [13-16]. Their confusing clinical appearance, diagnostic difficulties (many of them being confirmed only intraoperatively), histogenesis, the wide variety of anatomo-pathological forms, the staging and treatment of malignant ovarian tumors remain issues that must be solved by oncology gynecology [17- 19].

According to the chemical theory of ovarian oncogenesis, the transformation of normal cells into blastoma cells is caused by carcinogenic substances that enter the body from outside or are formed in the human body as a result of changes in metabolism [20-22].

Carcinogenic substances actslowly, not initially causing obvious changes in the tissues. Only after a fairly long latent period occurs tumor growth phenomena, sometimes in places other than the one where the substances are administered [23- 26].

\section{Experimental part}

Material and methods

The study was conducted on a group of 64 patients admitted to the Obstetrics-Gynecology Clinic of the Clinical Hospital in Galati. All the cases were diagnosed with ovarian cancer in the period J anuary 2014-December 2017.

The data obtained were statistically processed and consist of the objectification of risk factors, clinical diagnostic criteria, histopathological type and surgical technique applied. The statistical processing of this material, folowing the mentioned criteria, provides a basis for discussion on the complex problem of malignant ovarian tumors.

\section{Results and discussions}

We divided the group into two large age groups with an increased incidence of ovarian cancer: group I represented the number of cases between 41-71 years, in which 36 cases were recorded, representing $56.25 \%$ of the total cases studied and group II aged 18-40 years represents a total of 28 cases and $43.75 \%$, which is comparable to the percentage of cases recorded in the first group.

Ovarian cancer is the 9th neoplasia in terms of incidence in women and the fifth cause of death in women. The lifetime risk of a female invasive ovarian cancer is 1 to 71 and the risk of death is 1 to 95 .

We tried to focus our risk factors on our cases, the results being shown in table 1 .

\begin{tabular}{|l|l|l|}
\hline Age & $\begin{array}{l}\text { Limits } \\
\text { average }\end{array}$ & $\begin{array}{r}18-76 \text { years } \\
-46 \text { years }\end{array}$ \\
\hline Origin & $\begin{array}{l}\text { rural } \\
\text { urban }\end{array}$ & $\begin{array}{l}36 \text { cases } \\
28 \text { cases }\end{array}$ \\
\hline Marital status & $\begin{array}{l}\text { married } \\
\text { unmarried }\end{array}$ & $\begin{array}{c}60 \text { cases } \\
4 \text { cases }\end{array}$ \\
\hline Nulliparous & & 34 cases \\
\hline Significant gynecological history & & 20 cases \\
\hline
\end{tabular}

Table 1

RISK FACTORS IN OUR CASES

*email: elena.mihalceanu@umfiasi.ro; mihaeladebita@uahoo.co 
There are two hypotheses regarding ovarian carcinogenesis, namely that of Fathalla's uninterrupted ovulation in 1971 and the action of gonadotrophins.

Ovulation that occurs between $20-29$ years seems to have the most impact on risk factors. For each year of ovulation the cancer risk increases by $6 \%$, and in the period 20-29 years by $20 \%$. For each year of ovulation inhibited with combined oral contraceptives, the risk decreases by $8 \%$, with the use period beeing significant.

Nuliparity, early menarhas, late menopause increase the risk cancer, while women with high parity have a lower incidence of ovarian cancer, each birth gives a 10-16\% reduction in risk, the effect diminishing over time. The interrupted pregnancies also provide protection.

Lactation reduces risk by suppressing ovulation, the effect being stronger in the months immediately following birth, reducing the risk by $1 \%$ for each lactation month. Reversed effect was reported for prolonged breastfeeding.

Ovarian cancer is a condition that does not respect an age limit, occurring at any age, but reaching a maximum incidence in women over 45 years old, pre- or postmenopausal. It seems that with the end of genital function, the ovary suffers, in a high percentage, processes of potentially malignant cell degeneration [27-29].

The risk factors confirmed in the aetiology of ovarian cancer are age and genetic risk. The distribution by age group of the patients belonging to the studied group is shown in table 2.

Table 2

AGE DISTRIBUTION OF PATIENTS

\begin{tabular}{|c|c|c|}
\hline Age (years) & Case numbers & $\%$ \\
\hline Under 20 & 2 & 3.12 \\
\hline $21-30$ & 8 & 12.50 \\
\hline $31-40$ & 18 & 28.12 \\
\hline $41-50$ & 8 & 12.50 \\
\hline $51-60$ & 14 & 21.87 \\
\hline $61-70$ & 8 & 12.50 \\
\hline over71 & 6 & 9.39 \\
\hline
\end{tabular}

In the literature, the highest percentage of cases is considered to be between 40-60 years, this age interbal beeing considered as a risk factor [30-33]. On our cases, the incidence at these ages was 22 cases, representing $34.1 \%$ versus $60-70 \%$ as the percentage of published statistics in the literature.

In the second age group of the study group, 18 cases representing $64.28 \%$ were aged between $31-40$ years. This makes us affirm that malignant ovarian tumors are constantly increasing in number in younger ages, causing a mutation in incidence towards the third decade of life. We therefore believe, based on the increased incidence at this age, that the maximum incidence is considered to be between 30-60 years, on our group representing 40 cases with a percentage of $62.50 \%$.

On our studied group, we can say that the incidence of ovarian cancer by age group has three periods:

- Under 30 years, with low incidence;

-From 31 to 60 years of age when the incidence of ovarian cancer reaches its peak;

-After 61 years, when the incidence is again decreasing.

The study of the distribution of cases according to the patient origin shows, unlike other statistics, that in our clinic the number of the patients from the rural area (36-56.25\%) was higher than in the urban area (28-43.75\%).

The incidence of ovarian cancer is believed to be higher in unmarried, nulliparous women, as well as in those with a significant gynecological history (considered as risk factors).
12 cases had no pregnancy $-18.75 \%$, 18 cases, one pregnancy-28.12\%; 16 cases, two pregnancies-25.00\%; 6 cases, three pregnancies $-9.37 \% ; 6$ cases, four pregnancies - 9.37\%; 6 cases, five pregnancies $-9.37 \%$.

Because 46 cases representing $71.87 \%$ had a low number of pregnancies or were nuliparous, we can consider these parameters as risk factors.

The gynecological history, like menstruation disorders and surgeries on uterus were present in 20 patients (31.25\%).

Menarha at $81.40 \%$ of the patients appeared at the age of 13-14 years.

Initial symptoms presented by the patients of our casuistry at admission were: abdominal pain 56 cases (87.50\%), abdomen enlargement, 16 cases $(25.00 \%)$, metrorrhagia, 12 cases (18.75 lumbar pain, 10 cases (15.62\%), fetid leucorrhea, 8 cases $(12.50 \%)$, palpable transabdominal pelvic formation 2 cases $(3.12 \%)$, weight loss, 2 cases ( $3.12 \%)$, urine retention 2 cases $(3.12 \%)$, fever 2 cases $(3.12 \%)$.

Monosymptomatic manifestations were found in 38 cases $(59.37 \%)$, being abdominal pain, metrorrhagia and leukorrheic leakage. 30 cases were polysymptomatic (46.87\%), the associations of symptoms being: abdominal pain with abdominal volume increase, abdominal pain with metrorrhagia, abdominal pain with lumbar pain and metrorrhagia.

By reporting these symptoms to the time elapsed from their appearance to the presentation to the physician of the patients, it was found a time period between two weeks and two years.

The occurrence of malignancy signs: the fixation of the ovarian tumor, the folding of the Douglas recess, the intensive pain produced by the compression of the nerve tracts or the infiltration of the rectum, the bladder, ascites in some of our cases allowed for a certain diagnosis of cancer, but gave the patients a minimum chance of postoperative survival [34-38].

Table 3

DIAGNOSISAT ADMISSON

\begin{tabular}{|l|c|}
\hline Diagnosis at admission & Cases number \\
\hline Ovar tumor & 22 \\
\hline Pelvic tumor & 14 \\
\hline Malign ovarian tumor & 8 \\
\hline Extensive ovarian tumor & 2 \\
\hline leiomyoma of uterus & 12 \\
\hline pelvic peritonitis & 2 \\
\hline Cystic metritis & 4 \\
\hline
\end{tabular}

In 32 cases (50\%) preoperative diagnostic errors were in the order of frequency: pelvic tumor, fibromatous uterus, pelvic piperitonitis, cystic metritis.

Noteworthy, however, that these errors also address disorders of the genital sphere, which, have very close symptomatic symptoms [39- 42].

On our studied group, two large lots are distinguished:

- a lot with 24 cases detected in advanced stages (III and IV);

-an even larger lot of 38 cases that were detected in stage I.

- Stage II was present in only 2 cases.

The results of the study of these elements are shown in table 4.

Histological types of tumors was based on the Histological Classification of Ovarian Tumors (WHO) model.

In ourstudy group, the type of tumor most commonly encountered was represented by epithelial tumors, which 
Table 4

THE ELEMENTS THAT HAVE BEEN TAKEN INTO ACCOUNT FOR THE STAGING OF OVARIAN CANCER IN THE STUDIED GROUP

\begin{tabular}{|l|c|c|}
\hline Intraoperative & $\begin{array}{c}\text { Number of } \\
\text { cases }\end{array}$ & $\%$ \\
\hline ascites & 14 & 21.87 \\
\hline vegetation on the surface & 16 & 25.00 \\
\hline vegetation intracystic & 4 & 6.25 \\
\hline subdiaphragmatic metastases & 24 & 37.50 \\
\hline
\end{tabular}

accounted for $84.90 \%$ of the total anatomopathological formations.

The type of surgery was performed according to the appearance of the lesion and the local conditions, the presence or absence of metastases, and the age of the patient (table 5).

Table 5

TYPES OF INTERVENTIONS IN CASE STUDIES

\begin{tabular}{|l|c|c|}
\hline \multicolumn{1}{|c|}{ Types of interventions } & $\begin{array}{c}\text { Cases } \\
\text { numbers }\end{array}$ & $\%$ \\
\hline tumorectomy & 10 & 15.60 \\
\hline unilateral annexectomy & 6 & 9.30 \\
\hline bilateral anexectomy & 10 & 15.60 \\
\hline subtotal hysterectomy + tumorectomy & 4 & 6.20 \\
\hline $\begin{array}{l}\text { subtotal hysterectomy + bilateral } \\
\text { anexectomy }\end{array}$ & 12 & 18.70 \\
\hline $\begin{array}{l}\text { total hysterectomy + unilateral } \\
\text { annexectomy }\end{array}$ & 4 & 6.20 \\
\hline $\begin{array}{l}\text { total hysterectomy + bilateral } \\
\text { anexectomy }\end{array}$ & 10 & 15.60 \\
\hline total laparotomy + biopsy & 8 & 12.40 \\
\hline
\end{tabular}

Surgical treatment was completed with chemotherapy and radiotherapy and postoperative evolution was good. Using this radio-chemo-surgical complex treatment, survival over 3 years was achieved in most patients.

Surgical treatment, as the initial and main treatment method, should provide a more accurate assessment of the lesions and staging, maximum possible excision, fixation of the adjuvant therapeutic protocol and prognosis [43 - 48].

\section{Conclusions}

Observations made on the presented group regarding the high percentage of cases diagnosed at an early stage did not overlap with the literature data, constituting a histological surprise. Because the group presented is relatively small, the results obtained on the risk factors do notallow us to define a clear opinion on their significance in the etiopathogenesis of ovarian cancer, but the presence of some to a fairly large number of our cases makes us not ignore them.

Treatment should be multifactorial, chemotherapy and radiotherapy being adjuvant methods currently used.

\section{References}

1.BERRINO F, CAPOCACCIA R, COLEMAN MP, ESTEVE J, GATTA G, HAKULINEN T, et al. Survival of cancer patients in Europe: the EUROCARE-3 study. Ann Oncol 2003; 14 Suppl 5.

2.BEYER T, TOWNSEND DW, BRUN T, KINAHAN PE, CHARRON M, RODDY R, JERIN J, YOUNG J, BYARS L, NUTT R: A combined PET/CT scanner for clinical oncology. J Nucl Med 2000, 41:1369-79

3.BREWSTER WR, Temporal trend in ovarian cancer:incidence and mortality across Europe, Nature Clinical Practice Oncology, 2005;2:286287.

4.CALOF AL, Human Microscopic Anatomy:Femele Reproductive System I:Ovaries, Color Textbook of Histology, $2^{\text {nd }}$ Edition, 2006, Chapter 20, pp461-472.
5.CERNEA N., Dezvoltarea embriologica a ovarului, Ovarul functii si disfunctii, Ed. Medicala Universitatea Craiova, 2000, cap.2:11-21. 6.CHAN JK, LIN YG, LOIZZI V, GHOBRIEL M, DISAIA PJ, BERMAN ML.Borderline ovarian tumors in reproductive-age women. Fertilitysparing surgery and outcome., J Reprod Med 2003; 48(10): 756-60.

7.CHEN LEE-MAY BEREK J.S., Gynecologic Neoplasms in Cancer treatment, Haskell C.M.(ed), fifth edition, W.B. Saunders Company, 2000, pp 900-924.

8.CHO EY, CHOI Y, CHAE SW, SOHN JH, AHN GH. Immunohistochemical study of the expression of adhesion molecules in ovarian serous neoplasms. Pathol Int 2006; 56: 62-70.

9.HINGANU, D., HINGANU, M.V., MIHALCEANU, E., CALIN, A.M., PANGAL, A., COSTACHESCU, G., ROMILA, A., Rev Chim (Bucharest), 69, no. 3, 2018, p. 714

10.CHOUDHURY M, GOYAL S, PUJANI M, A cytohistological study of Ki-67 expression in ovarian tumors. Indian J Pathol Microbiol 2011, 54:21-42.

11.DANCIULESCU MIHAELA, Cancerul ovarian epitelial, Ed.Medicala universitara Craiova, 2007.

12.TOMA, A.G., SALAHORU P., HINGANU, M.V., HINGANU, D., DIMA COZMA, L. L., PATRASCU, A., GRIGORESCU C. Rev. Chim.(Bucharest), 70, no.1, 2019, p. 143

13.DE SANTIS G, MIOTTI S, MAZZI M, CANEVARI S, TOMASSETTI A. Ecadherin directly contributes to PI3K/AKT activation by engaging the PI3K-p85 regulatory subunit to adherens junctions of ovarian carcinoma cells. Oncogene 2009; 28(9): 1206-1217.

14.IONESCU C.A., VLADAREANU S., PLES L., DIMITRIU M.C.T., FURAU G.O., VLADESCU T.C., CALIN A.M., OPRESCU N.D. Rom J Morphol Embryol, 58, no.1, 2017, p. 219.

15.GRIGORIU, R., CALIN, A.M., ARBUNE, M., MIHALCEANU E., ONOFRIESCU M., IONESCU C., Rev. Chim. (Bucharest), 67, no.2, 2016, p. 366.

16.DEAVERS MT, GERSHENSON DM, TORTOLERO-LUNA G, et al. Micropapillary and cribriform patterns in ovarian serous tumors of low malignant potential: a study of 99 advanced stage cases. Am J Surg Pathol 2002; 14(3): 129-143.

17.DEHARI R, KURMAN RJ, LOGANI S, et al. The development of highgrade serous carcinoma from atypical proliferative (borderline) serous tumors and low-grade micropapillary serous carcinoma: a morphologic and molecular genetic analysis. Am J Surg Pathol 2007; 31:1007-1012. 18.ELISABETH DE VRIES, GRONINGEN NL, Functional Imaging in Ovarian Cancer, Special Symposium, Ovarian Cancer, Esmo 2010, Milano

19.GERSHENSON DM. Management of ovarian germ cell tumors.J Clin Oncol 2007;25 (20):2938-2943.

20.GILKS BLAKE C. Subclassification of ovarian surface epithelial tumors based on correlation of histologic and molecular pathologic data. Int J Gynecol Pathol 2004; 23: 200-5.

21.HINGANU, D., HINGANU, M.V., BULIMAR, V,. ANDRONIC, D., Correlation Criteria Between Extramural Invasion of Blood Vessels and Immunohistochemical Markers in the Processes of Neovasculogenesis. Rev. Chim. (Bucharest), 69, no.2, 2018, p. 371374

22.ALBU, D.R., MIHALCEANU, E. PANGAL, A., VULPOI, C., ONOFRIESCU, M., NITOI, L., MIHAILA, A., COSTACHESCU, G., CONSTANTINESCU, D., DUMITRASCU, I. Can Osteopontin Be Considered a Biomarker for Endometriosis? Rev. Chim. (Bucharest), 68, no.9, 2017, p.: 2132-2134.

23.GILKS CB, IONESCU DN, KALLOGER SE, et al. Tumor cell type can be reproducibly diagnosed and is of independent prognostic significance in patients with maximally debulked ovarian carcinoma. Hum Pathol2008; 39: 1239-1251.

24.GORE M. Intraperitoneal chemotherapy in ovarian cancer remains experimental. J.Clin Oncol 2006; 24(18):4528-4530.

25.GU P, PAN LL, WU SQ, SUN L, HUANG G: CA 125, PET al one, PET$\mathrm{CT}, \mathrm{CT}$ and $\mathrm{MRI}$ in diagnosing recurrent ovarian carcinoma $\mathrm{A}$ systematic review and meta-analysis.Eur J Radiol 2008, 29. 
26.J EMAL AHMEDIN, SIEGEL REBECCA, WARD ELIZABETH, MURRAY TAYLOR, XU JIAQUAN, THUN MICHAEL J. Cancer statistics. Cancer J Clin 2008; 58:471-96.

27.KACAR S, FILINTE D. Tp53 Expression and Ki-67 Proliferation Index in Surface Epithelial- Stromal Tumors of the Ovary and Their Relationship with the Histopathological Prognostic Parameters. Gynecol Oncol 2004, 144-156.

28.KARSELADZE, A.I., Serous borderline ovarian tumors: where are we now? Eur J Gynaecol Oncol 2005; 26(4): 355-61.

29.KITAI IMA K, MURAKAMI K, YAMASAKI E, KAJI Y, FUKASAW A I, INABA N, SUGIMURA K:Diagnostic accuracy of integrated FDG-PET/ contrast-enhanced CT in staging ovarian cancer: comparison with enhanced CT.Eur J Nucl Med Mol Imaging 2008, 35:1912-20.

30.KOONINGS, P.P., et al., Relative frequency of primary ovarian neoplasms:a 10- Koensgen D, Freitag C, Klaman I. Expresion and Localization of Ecadherin in Epithelial Ovarian Cancer. Anticancer Research J uly 2010; 30(7):2525-2530. year review. Obstet Gynecol 1989; 74(6): $921-6$

31.KURMAN RJ, SHIH IEM. Pathogenesis of ovarian cancer: lessons from morphology and molecular biology and their clinical implications. Int J Gynecol Pathol 2008; 27 : 151-160.

32.KUROKAWA T, YOSHIDA Y, KAWAHARA K, TSUCHIDA T, FUJ IBAYASHI Y, YONEKURA Y, KOTSUJI F: Whole-body PET with FDG is useful for following up an ovarian cancer patient with only rising CA-125 levels within the normal range. Ann N ucl Med 2002, 16:491-493

33.KUROKAWA T, YOSHIDA Y, KAWAHARA K, TSUCHIDA T, OKAZAWA $H$, FUJ IBAYASHI Y, YONEKURA Y, KOTSUJI F: Expression of GLUT-1 glucose transfer, cellular proliferation activity and grade of tumor correlate with [F-18]-fluorodeoxyglu cose uptake by positron emission tomography in epithelial tumors of the ovary,Int J Cancer 2004, 10;109:926-32

34.MARKMAN M,WALKER JL.Intraperitoneal chemotherapy in epithelial ovarian cancer.Ann Oncol.2000; 10 (suppl.1):26-32.

35.HÎNGANU MV, HÎNGANU D, FRÂNCU LL. Rom J Morphol Embryol, 54, no.3, 2013, p. 561-565.

36.NAKAYAMA, N., TANABE, S., LOIZUMI, W., HIGUCHI, K., SASAKI, T., NAKATANI, K., SHIMODA, T., NISHIMURA, K., KOBAYASHI, N., MITOMI, H., SAIGENJI, K. - A case of long-term survival of 3-years 4 month after combination chemotherapy of MTX, 5-FU and low-dose CDDP (MFP) for type 4 gastric cancer with pleuritis, peritoneal dissemination and Krukenberg tumor. Gan To Kagaku Ryoho., 2006, 33:1641.
37.REEDE., ALTAHA R. Ovarian cancer. In:Abraham J , Allegra C J Gulley $J$,eds. Bethesda Handbook of clinical oncology.2nd edition. Philadelphia:Lippincott Williams \&Wilkins,2005:227-236.

38.ROBIN LH,WITTEKIND CH, Tumorile genitale feminine. In:UICC.TNM-Clasificarea tumorilor maligne 6th ed. New-York: WileyLiss, 2002 Versiunea românã.Editura Ministerului Sanatatii 2005:165170.

39.HINGANU D, EVAI, STAN C, HINGANU MV. Rom J Morphol Embryol, 57, no.1, 2016, p. 161-165

40.SHIH I, KURMAN R, Pathogenesis of ovarian cancer. Lessons from morphology and molecular biology and their clinical implications. Int J Gynecol Pathol 2008; 27(2): 151-160.

41.CALIN, A.M., DEBITA, M., CIURCANU, O.E., SCUTARIU, M.M., SZALONTAY, A.S.. Rev. Chim. (Bucharest), 68, no.10, 2017, p. 24432447.

42.CIURCANU, O.E., STEFANESCU, O., SCUTARIU, M.M., STELEA, C.G., Importance of the Chemistry of Local Anesthetic in Modulation of Cardio-vascular Response. Rev. Chim.(Bucharest), 67, no.3, 2016, p.566.

43.SHIH IEM, KURMAN RJ. Molecular pathogenesis of ovarian borderline tumors: new insights and old challenges. Clin Cancer Res 2005; 11:7273-7279.

44.SHIH IEM, KURMAN RJ. Ovarian tumorigenesis: a proposed model based on morphological and molecular genetic analysis. Am J Pathol 2004; 164:1511-1518.

45.SONDA Y, SPRINGGS D. Ovarian cancer.În Chang AE, ed. Oncologyan evidence based approach.New-York:Springer, 2006:903-927.

46.TIRNOVEANU MIHAELA, ONOFRIESCU M, LUCA A., MUSCA SIMONA, TRIFAN CORINA, FLUTUR DIANA, Struma ovarii-tumorã ovarianã cu potenpal secretant, vol.rezumate Congres Brasov 2007, pag 156.

47.TOTHILL RW, TINKER AV, GEORGE J etal. Novel molecular subtypes of serous and endometrioid ovarian cancer linked to clinical outcome. Clin Cancer Res 2008; 14: 5198-5208.

48.TSUCHIDA T, OKAZAWA H, MORI T, KOBAYASHI M, YOSHIDA Y, FUJ IBAYASHI $Y$, ITOH $\mathrm{H}$ : In vivo imaging of estrogen receptor concentration in the e ndometrium and myometrium using FES PET - influence of menstrual cycle and endogenous e strogen level. Nucl Med Biol 2007, 34:205-10.

$\overline{\text { Manuscript received: } 5.08 .2018}$ 
